\title{
Deciphering heavy metal contamination zones in soils of a granitic terrain of southern India using factor analysis and GIS
}

\author{
D Purushotham ${ }^{1}$, Mahjoor Ahmad Lone $^{1}$, Mehnaz Rashid ${ }^{1, *}$, \\ A NARsing RAO ${ }^{2}$ and Shakeel Ahmed ${ }^{1}$ \\ ${ }^{1}$ CSIR-National Geophysical Research Institute, Hyderabad 500 606, India. \\ ${ }^{2}$ Department of Geology, Osmania University, Hyderabad 500 00\%, India. \\ ${ }^{*}$ Corresponding author.e-mail: geo.mehnaz@gmail.com
}

\begin{abstract}
Soil contamination by heavy metals has been a major concern for last few decades due to increase in urbanization and industrialization. The main objective of this research was to identify the heavy metal contaminated zones in the study area. Twenty five soil samples collected throughout the agriculture, residential and industrial areas were analysed by X-ray Fluorescence Spectrometer (XRF) for trace metals and major oxides. These metals can affect the quality of soil and infiltrate through the soil, thereby causing groundwater pollution. Based on the chemical analysis of major oxides $\left(\mathrm{SiO}_{2}, \mathrm{Al}_{2} \mathrm{O}_{3}, \mathrm{Fe}_{2} \mathrm{O}_{3}\right.$, $\mathrm{MnO}, \mathrm{MgO}, \mathrm{CaO}, \mathrm{Na}_{2} \mathrm{O}, \mathrm{K}_{2} \mathrm{O}, \mathrm{TiO}_{2}$, and $\mathrm{P}_{2} \mathrm{O}_{5}$ ) and their distribution; it is observed that these soils are predominantly siliceous type with slight enrichment of alumina component in the study area. Correlation matrix (CM) and factor analysis (FA) is employed to the heavy metal variables, viz., $\mathrm{Ba}, \mathrm{Cr}, \mathrm{Cu}$, $\mathrm{Ni}, \mathrm{Pb}, \mathrm{Rb}, \mathrm{Sr}, \mathrm{V}, \mathrm{Y}, \mathrm{Zn}$ and $\mathrm{Zr}$ of the soil to determine the dominant factors contributing to the soil contamination in the area. In the analysis, five factors emerged as significant contributors to the soil quality. The total contribution of these five factors is about $90 \%$. The contribution of the first factor is about $45 \%$ and has significant positive loadings of $\mathrm{Co}, \mathrm{Cr}, \mathrm{Cu}, \mathrm{Ni}$ and $\mathrm{Zn}$. The contribution of second factor is $22 \%$ and has significant positive loadings of Rb, Sr and Y. The contribution of third, fourth and fifth factors is 10,8 and $5 \%$ and show positive loadings for lead, molybdenum and barium respectively to the soil contamination. The spatial variation maps deciphering different zones of heavy metal concentration in the soil were generated in a GIS (geographic information system) based environment using ArcGIS 9.3.1. The results reveal that heavy metal contamination in the area is mainly due to anthropogenic activities.
\end{abstract}

\section{Introduction}

Soil is one of the major life support system on Earth. Heavy metals are considered as one of the most serious pollutants in the environment due to their toxicity, persistence and bio-accumulation. These elements can bio-accumulate in plants and animals eventually making their way to humans through food chain (Frink 1996; Abrahams 2002). Soil samples represent an excellent media to monitor heavy metal pollution because anthropogenic heavy metals are usually deposited in top soils (Govil et al. 2001; Romic and Romic 2003). The contamination of soils is mainly in industrial regions and with centers of large settlements where factories are located. Much interest has focused

Keywords. Heavy metals; factor analysis; XRF; Maheshwaram; GIS; anthropogenic. 
upon the presence of toxic heavy metals, especially cadmium, chromium, copper, mercury, nickel, lead and zinc either because of their common occurrence or because of their toxicity at quite low concentrations. Although some heavy metals are necessary as plant micronutrients $(\mathrm{Zn}, \mathrm{Cu}, \mathrm{Mn}, \mathrm{Fe}$ and $\mathrm{Co})$ and other heavy metals ( $\mathrm{Pb}, \mathrm{Cd}, \mathrm{Ni}, \mathrm{Hg}$ and $\mathrm{Cr}$ ) which may enter the food chain or leach down to groundwater and contaminate drinking water resources (Jeevan 1998). Therefore, analysis of heavy metals in soil offer an ideal means to monitor not only the pollution of soil itself, but also to quantify the overall environment, as reflected in soil (Denny 1987; Olade 1987). Many researchers like Li and Huang (2007); Krishna and Govil (2008); Ahmad and Goni (2010); Karanlı et al. (2011) and Wu et al. (2011) have reported the influence of heavy metal contamination in soils of different regions.

The study area in the vicinity of Hyderabad international airport that has been expanding at a fast pace and now has the distinction of being one of the fastest growing urban centers in the Hyderabad city. Manufacturing industries producing chemicals, pharmaceuticals, batteries, foundries, metal plating and plastic product have engulfed the area. Most of these industries directly release their effluent into nearby areas and the solid waste is randomly dumped on available open land leading to environmental degradation especially the land degradation causing heavy metals pollution. The study aimed at determining the natural background levels of heavy metals as a guide for future pollution monitoring with suitable recommendations for mitigation of environmental impacts.

Water stress in hard rock aquifers of south India has been increasing day by day due to rapid urbanization and industrialization. Hence any contamination in the soils will directly cause severe pollution of the groundwater. Maheshwaram

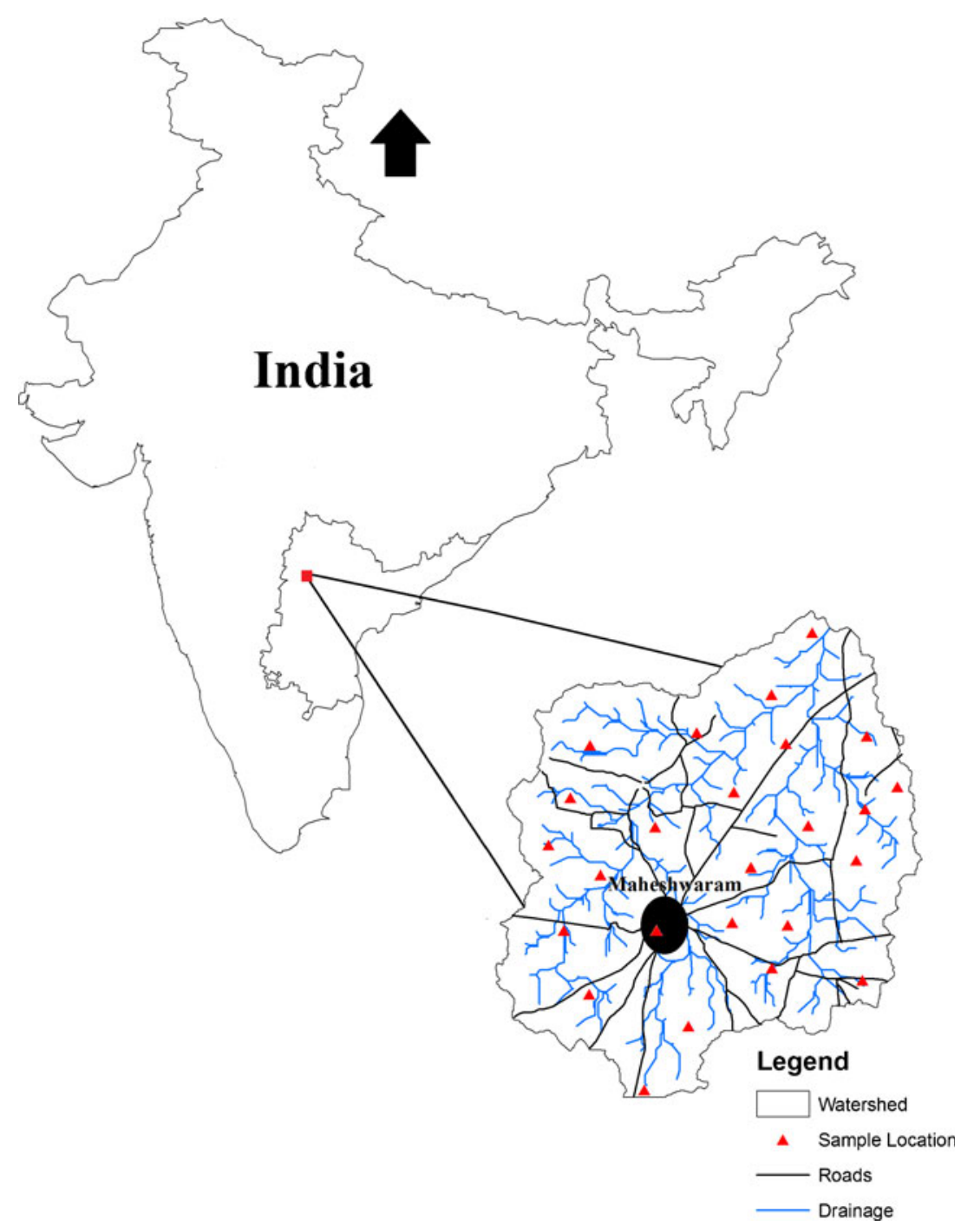

Figure 1. Location map of the study area showing soil sample points. 
watershed is a typical representative of a hard rock south Indian area where huge stress on groundwater resource has been witnessed due to increase in urbanization as well as industrialization. Hence assessment of heavy metal contamination in the soils of Maheshwaram watershed will play a vital role in the sustainable management of groundwater resources in the area.

\section{Study area}

The Maheshwaram watershed has an area of $53 \mathrm{~km}^{2}$ (figure 1). In general the topography is flat. A network of first and second order streams shows dendritic to sub-dendritic type of drainage pattern with no major streams. The study area is located in sem-arid climatic zone. Average annual rainfall in the area is $884.1 \mathrm{~mm}$ while maximum precipitation occurs during June-September with the onset of southwest monsoon. The temperature ranges from $22^{\circ}$ to $44^{\circ} \mathrm{C}$. The soil cover is of welldeveloped residual soil, characteristic of weathered granite. The soil is yellowish to brown-reddish sand with varying content of silt. Soil is fairly permeable and the infiltration rate can absorb most of the rain except for more intensive rains, which can cause considerable surface flow and erosion. Geology of the area is relatively homogenous comprising of Precambrian granites mostly

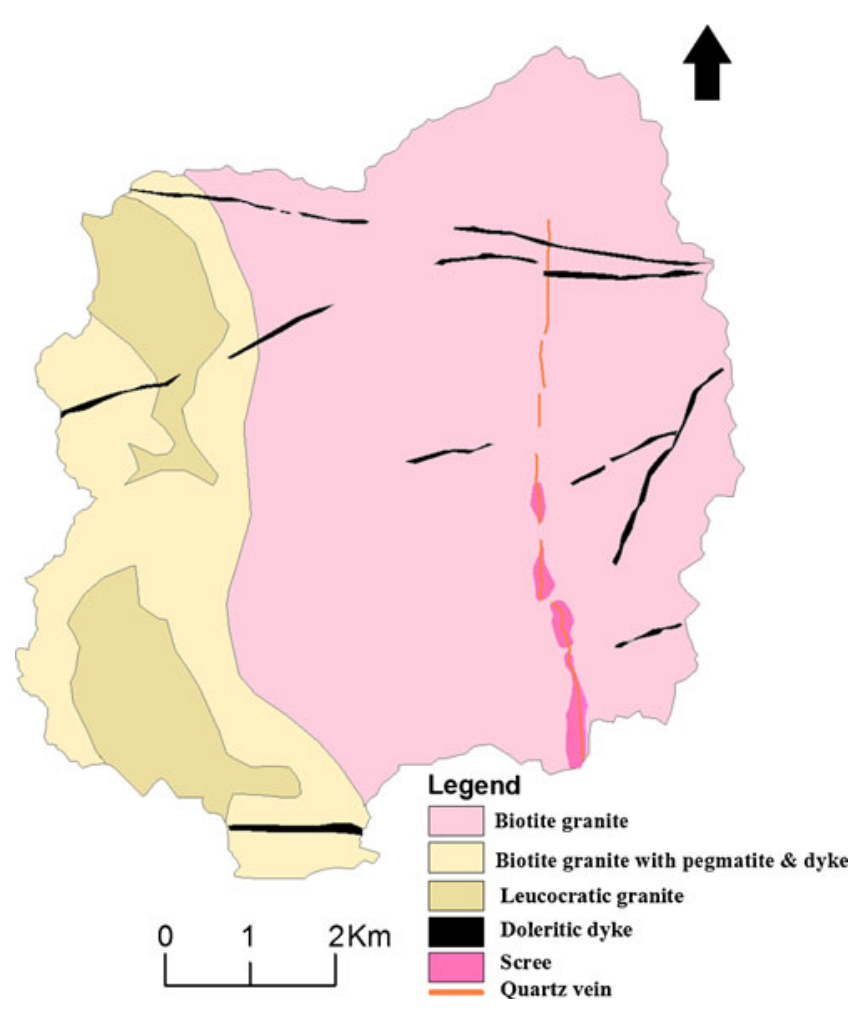

Figure 2. Geology of the study area. pink and grey granites (figure 2) (Dewandel et al. 2006). Basic enclaves, aplite, pegmatite, epidote and quartz veins and dolerite dykes frequently traverse the area. Biotite granite covers a major part of Maheshwaram with porphyritic feldspars. Granites are intruded by quartz and dolerite dykes of several generations and are well exposed in northern and western parts of watershed. These dykes form important structural feature controlling the movement of groundwater in the region. Joints are the most commonly observed structural feature in the study area. Vertical joints act as conduits for transfer of water whereas horizontal joints help in maintaining the lateral continuity of the aquifer.

\section{Methodology}

\subsection{Sampling and analytical procedures}

To avoid influence from various arbitrary surface conditions like waste and humus and to assure natural in-phase soil, the selected depth of sampling was from 10 to $15 \mathrm{~cm}$ below the surface to $25 \mathrm{~cm}$ depth (Chang et al. 1984). In all 25 representative soil samples collected from the study area (figure 1), every precaution was taken to avoid contamination during sampling. The samples were collected in self-locking polythene bags and were sealed in double bags. The soil samples were air dried and kept in oven for two days at $60^{\circ} \mathrm{C}$. The oven dried samples were then disaggregated with mortar and pestle and sieved through $2 \mathrm{~mm}$ sieve. The samples were ground in agate swing grinding mill to make the sample homogenous and to get accurate analytical data, as it is essential that the surface layer should represent the bulk specimen. Weighing of sample was carried out using analytical balance with precision as low as $0.0001 \mathrm{~g}$. Pressed pellets are prepared by using collapsible aluminium cups. These cups were filled with boric acid, and $1 \mathrm{~g}$ of the finely powdered sample was put on top of the boric acid and pressed under a hydraulic press at 20 tons of pressure to get a pellet for XRF spectrometry. Elemental composition was determined using an X-ray fluorescence spectrometer, type Philips Magix PRO model PW 2440 XRF with Rhodium $4 \mathrm{KW}$ X-Ray tube. High level performance of the system enables a very sensitive and accurate determination of major and trace elements, viz., $\mathrm{Ba}, \mathrm{Co}, \mathrm{Cr}, \mathrm{Cu}, \mathrm{Mo}, \mathrm{Ni}, \mathrm{Pb}, \mathrm{Rb}, \mathrm{Sr}$, $\mathrm{V}, \mathrm{Y}, \mathrm{Zn}$ and $\mathrm{Zr}$ as it is possible to measure the elements of interest from boron to uranium. It is a sequential instrument with a single goniometerbased measuring channel covering the complete elemental range. The instrument is microprocessor controlled for maximum flexibility. 


\section{Results and discussion}

\subsection{Factor analysis}

Factor analysis is a variable reduction procedure. It is useful when one has obtained data on a large number of variables, and believes that there is some redundancy in those variables. In this case, redundancy means that some of the variables are correlated with one another, possibly because they are measuring the same construct. With factor analysis it is possible to get associations of heavy metals in factors that would give some information about the behaviour and the source of pollution (Bai et al. 2009). Multivariate analysis like principal component analysis (PCA) and correlation matrix (CM) has been proved to be an effective tool for source identification of heavy metals (Bai et al. 2011). Each variable is assumed to be dependent on a linear combination of the common factors, and the coefficients are known as loadings (Davis 1986). The heavy metals composition of soil samples were subjected to correlation and factor analysis (CA, FA) to understand the controlling covariance structure between the variables. Each variable was standardized to the mean 0.0 , and variance 1.0, to avoid the problem of having one variable with large variance unduly influencing the determination of factor loadings. FA code from Matlab 6.5 (2002) is used for the purpose. The result of FA based on the most significant first five factors shows that about $90 \%$ of the total variance and includes 11 variables of the observed 13 variables. Hence, the first five factors can be used to explain the factors contributing to soil contamination in the area. The factor loadings, the corresponding eigenvalues and the percent of variance contribution by each factor determine the natural background levels of heavy metals (tables 1, 2 and 3).

\subsubsection{Factor-I}

The contribution of the factor FA-I is $45 \%$ of the total variance and has the largest eigenvalue 5.84 (table 2). FA-I has high positive loadings of $\mathrm{Co}, \mathrm{Cr}$, $\mathrm{Cu}, \mathrm{Ni}$ and $\mathrm{Zn}$ in the range $0.58-0.92$. The correlation coefficient between $\mathrm{Co}, \mathrm{Cr}, \mathrm{Cu}$ and $\mathrm{Ni}$ is more than 0.80 which is significant at one percent level.

\subsubsection{Factor-II}

The contribution of the 2nd factor FA-II is $22 \%$ of the total variance and has the second largest eigenvalue 2.83. FA-II has high positive loadings of 0.74-0.89. The correlation coefficient between $\mathrm{Rb}$, $\mathrm{Sr}$ and $\mathrm{Y}$ is more than 0.70 which is significant at one percent level.

\subsubsection{Factor-III}

The contribution of the 3rd factor FA-III is $10 \%$ of the total variance and has the eigenvalue 1.27. FA-III has high positive loadings of lead 0.71 .

\subsubsection{Factor-IV}

The contribution of the 4 th factor F-IV is $8 \%$ of the total variance and has the eigenvalue 1.00. FA-IV has high positive loadings of molybdenum (0.92).

\subsubsection{Factor- $V$}

The contribution of the 5th factor, F-V is $5 \%$ of the total variance and has the eigenvalue in the range 0.68 . FA-V has moderate positive loadings of barium (0.64).

The result of FA based on the most significant first five factors shows that about $90 \%$ of the total

Table 1. Correlation matrix of heavy metals as determined from factor analysis.

\begin{tabular}{lrrrrrrrrrrrr}
\hline Elements & \multicolumn{1}{c}{$\mathrm{Ba}$} & $\mathrm{Co}$ & $\mathrm{Cr}$ & $\mathrm{Cu}$ & $\mathrm{Mo}$ & $\mathrm{Ni}$ & $\mathrm{Pb}$ & $\mathrm{Rb}$ & $\mathrm{V}$ & $\mathrm{Y}$ & $\mathrm{Zr}$ & $\mathrm{Sr}$ \\
\hline $\mathrm{Ba}$ & 1.00 & & & & & & & & & & \\
$\mathrm{Co}$ & 0.27 & 1.00 & & & & & & & & & \\
$\mathrm{Cr}$ & 0.39 & 0.89 & 1.00 & & & & & & & & \\
$\mathrm{Cu}$ & 0.35 & 0.83 & 0.80 & 1.00 & & & & & & & \\
$\mathrm{Mo}$ & -0.29 & -0.44 & -0.53 & -0.66 & 1.00 & & & & & & & \\
$\mathrm{Ni}$ & 0.31 & 0.84 & 0.93 & 0.71 & -0.40 & 1.00 & & & & & & \\
$\mathrm{~Pb}$ & -0.57 & -0.20 & -0.31 & -0.45 & 0.56 & -0.09 & 1.00 & & & & \\
$\mathrm{Rb}$ & -0.62 & -0.25 & -0.47 & -0.38 & 0.31 & -0.42 & 0.64 & 1.00 & & & \\
$\mathrm{~V}$ & 0.03 & 0.29 & 0.39 & 0.39 & -0.34 & 0.32 & -0.24 & -0.34 & 1.00 & & \\
$\mathrm{Y}$ & -0.76 & -0.23 & -0.39 & -0.27 & 0.20 & -0.42 & 0.49 & 0.90 & -0.19 & 1.00 & \\
$\mathrm{Zr}$ & 0.41 & -0.27 & -0.17 & 0.04 & -0.12 & -0.32 & -0.67 & -0.63 & 0.10 & -0.47 & 1.00 & \\
$\mathrm{Sr}$ & -0.36 & -0.13 & -0.30 & -0.26 & 0.25 & -0.36 & 0.37 & 0.73 & -0.24 & 0.71 & -0.38 & 1.00 \\
$\mathrm{Zn}$ & 0.22 & 0.48 & 0.61 & 0.50 & -0.16 & 0.54 & -0.11 & -0.46 & 0.38 & -0.37 & 0.02 & -0.24 \\
\hline
\end{tabular}


Table 2. Matrix of factor loadings as derived from factor analysis.

\begin{tabular}{lccl}
\hline Factor & $\begin{array}{c}\text { Eigen- } \\
\text { values }\end{array}$ & $\begin{array}{c}\text { Percent } \\
\text { contribution }\end{array}$ & \multicolumn{1}{c}{$\begin{array}{c}\text { Elements with } \\
\text { high loadings }\end{array}$} \\
\hline I & 5.84 & 45 & $\mathrm{Co}, \mathrm{Cr}, \mathrm{Cu}, \mathrm{Ni}$ and Zn \\
II & 2.83 & 22 & $\mathrm{Rb}, \mathrm{Sr}$ and Y \\
III & 1.27 & 10 & $\mathrm{~Pb}$ \\
IV & 1.00 & 8 & $\mathrm{Mo}$ \\
V & 0.68 & 5 & $\mathrm{Ba}$ \\
Total & 11.62 & 90 & 11 \\
\hline
\end{tabular}

Table 3. Summary of the percentage contribution of each factor in the factor analysis for heavy metals.

\begin{tabular}{lrrrrr}
\hline & \multicolumn{1}{c}{ F-I } & F-II & F-III & F-IV & F-V \\
\hline $\mathrm{Ba}$ & 0.21 & -0.49 & -0.30 & -0.12 & 0.64 \\
$\mathrm{Co}$ & 0.91 & 0.01 & 0.05 & -0.16 & 0.17 \\
$\mathrm{Cr}$ & 0.92 & -0.23 & 0.02 & -0.23 & 0.03 \\
$\mathrm{Cu}$ & 0.79 & -0.03 & -0.23 & -0.40 & 0.11 \\
$\mathrm{Mo}$ & -0.32 & 0.09 & 0.17 & 0.92 & -0.03 \\
$\mathrm{Ni}$ & 0.88 & 0.32 & 0.26 & -0.14 & 0.02 \\
$\mathrm{~Pb}$ & -0.16 & 0.28 & 0.71 & 0.38 & -0.16 \\
$\mathrm{Rb}$ & -0.29 & 0.83 & 0.46 & 0.07 & -0.01 \\
$\mathrm{Sr}$ & -0.14 & 0.74 & 0.14 & 0.13 & 0.04 \\
$\mathrm{~V}$ & 0.32 & -0.20 & -0.14 & -0.22 & -0.25 \\
$\mathrm{Y}$ & -0.19 & 0.89 & 0.20 & 0.01 & -0.34 \\
$\mathrm{Zn}$ & 0.58 & -0.31 & -0.09 & 0.07 & -0.11 \\
$\mathrm{Zr}$ & -0.25 & -0.37 & -0.86 & -0.02 & 0.03 \\
\hline
\end{tabular}

variance includes 11 variables (elements) of the observed 13 variables. Hence, the first five factors can be used to explain the factors contributing to soil contamination in the area.

\subsection{Land use/land cover change}

Land use/land cover maps of the year 2003 and 2009 were prepared using knowledge based supervised classification technique and maximum likelihood classifier. Change in land use/land cover plays an important role in changing the quality of water and soil of the area. Land use changes strongly influence soil moisture regime and soil Eh which could greatly affect solubility, toxicity, bioavailability and mobility of heavy metals and cause their redistribution in soils (Bai et al. 2010).

The results reveal that in the study area land use/cover is changing at rapid pace in the form of built-up. There is huge urbanization with chemical and pharmaceutical industries, electroplating, brick tiles, oil refineries, steel, plastic and glass manufacturing units and poultry farms. These anthropogenic activities pollute the soil both directly as well as indirectly. The detailed discussion regarding the anthropogenic source of these pollutants in soils of Maheshwaram has been discussed in the following paragraph.

This is one of the main causes for degrading soil and water quality in the area (figure $3 \mathrm{a}, \mathrm{b}$ ).
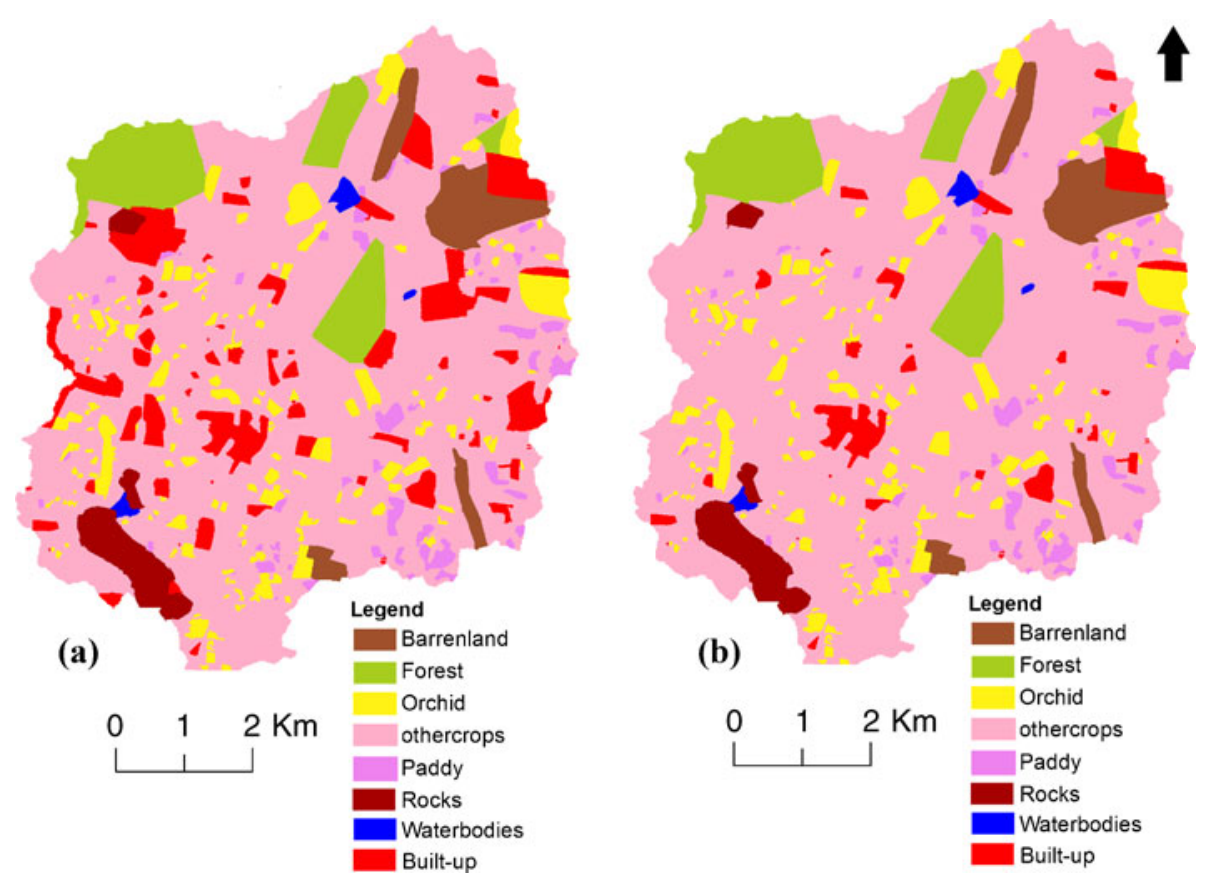

Figure 3. Change in land use/cover of the watershed from (a) 2003 to (b) 2009. 


\subsection{Analysis of heavy metals in soils}

Contamination of soil especially by heavy metals (atomic weight $>100$ ) appear to be virtually permanent, as heavy metals can be transformed from one chemical form to another through chemical and biochemical reactions but are not destroyed. The heavy metal (Ba, Co, Cr, Cu, Mo, $\mathrm{Ni}, \mathrm{Pb}, \mathrm{Rb}, \mathrm{Sr}, \mathrm{V}, \mathrm{Y}, \mathrm{Zn}$ and $\mathrm{Zr}$ ) concentrations of the study area are presented in table 4. To assess soil contamination in the study area, the concentrations of heavy metals and their spatial distribution was compared with heavy metal concentration in the earth's crust (Taylor and McLennan 1995) (table 5). Among the 13 heavy metals detected in the soils of study area, only $\mathrm{Sr}$ and $\mathrm{Zn}$ are within the permissible limit. The increased levels of barium, cobalt, chromium, copper, molybdenum, nickel, lead, rubidium, vanadium, yttrium and zirconium in the study area are major concern for the suitability in agricultural and other land management practices. The higher standard deviation observed for heavy metals $\mathrm{Cr}, \mathrm{V}, \mathrm{Sr}, \mathrm{Ba}, \mathrm{Zr}, \mathrm{Rb}$ and $\mathrm{Y}$ in soil suggests that these metals are not uniformly distributed in the study area. Out of the 25 soil samples, five samples for Mo and one sample for Co were found to be below detectable limit. Likewise the statistical summary given in table 5 and the box plot in figure 4 does not account for these samples for Mo and Co. Lead gives the least variation among the heavy metals while chromium and vanadium show highest variation in soil samples (table 5). Spatial variation maps (figure $5 \mathrm{a}-\mathrm{k}$ ) of the heavy metal contamination were prepared into three zones using I.D.W (inverse distance weighted) interpolation method in Arc GIS 9.3.1 for the heavy metals that exceed the desirable limit prescribed by Taylor and McLennan (1995). Although no measures are known that could be universally applied to choose the optimal set of parameters, cross-validation method is often used to select an interpolator from finite number of candidates (Davis 1987). The method is based on removing one data point at a time, performing the interpolation for the location of the removed point using the remaining samples (i.e., pretending that removed point does not exist), and calculating the difference (residual) between the actual value of the removed data point and the estimate for this point obtained from remaining samples. This scenario is repeated until every sample has been in turn removed. In this study the error estimation maps prepared by above said method show almost negligible deviation from

Table 4. Summary of the heavy metal concentration (in $\mathrm{mg} / \mathrm{kg}$ ) in soil samples from XRF data.

\begin{tabular}{|c|c|c|c|c|c|c|c|c|c|c|c|c|c|}
\hline $\begin{array}{l}\text { Sample } \\
\text { no. }\end{array}$ & $\mathrm{Ba}$ & Co & $\mathrm{Cr}$ & $\mathrm{Cu}$ & Mo & $\mathrm{Ni}$ & $\mathrm{Pb}$ & $\mathrm{Rb}$ & $\mathrm{V}$ & $\mathrm{Y}$ & $\mathrm{Zr}$ & $\mathrm{Sr}$ & $\mathrm{Zn}$ \\
\hline 1 & 578.9 & 11.9 & 58.0 & 23.8 & 1.1 & 39.7 & 52.1 & 126.9 & 80.7 & 27.6 & 636.6 & 108.5 & 39.5 \\
\hline 2 & 598.3 & 16.3 & 56.8 & 36.0 & 2.9 & 38.6 & 48.1 & 206.4 & 97.6 & 48.2 & 632.2 & 131.8 & 59.2 \\
\hline 3 & 646.2 & 21.6 & 69.2 & 33.8 & 3.6 & 60.2 & 63.5 & 161.3 & 123.3 & 30.7 & 441.7 & 104.2 & 51.1 \\
\hline 4 & 604.0 & 29.7 & 106.3 & 30.0 & 3.7 & 74.9 & 57.0 & 183.4 & 122.4 & 34.1 & 258 & 89.0 & 55.8 \\
\hline 5 & 624.1 & 12.6 & 49.2 & 27.1 & 5.3 & 26.3 & 54.3 & 247.4 & 101.8 & 58.4 & 858.3 & 170.6 & 60.4 \\
\hline 6 & 744.6 & 5.4 & 29.0 & 18.9 & 5.5 & 28.3 & 49.3 & 217.0 & 74.6 & 33.3 & 634.5 & 151.3 & 47.6 \\
\hline 7 & 130.3 & ND & 3.20 & 11.8 & 4.8 & 10.3 & 71.5 & 1314 & 18.4 & 153.3 & 66.3 & 295.4 & 25.3 \\
\hline 8 & 452.4 & ND & 15.4 & 12.3 & 7.8 & 20.9 & 60.2 & 332.7 & 59.8 & 57.7 & 671.5 & 121.7 & 28.5 \\
\hline 9 & 574.6 & 6.0 & 41.3 & 18.6 & 7.4 & 35.4 & 51.6 & 196.3 & 76.7 & 35.9 & 673.5 & 122.4 & 36.7 \\
\hline 10 & 726.3 & 6.2 & 32.2 & 20.1 & 5.0 & 20 & 39.3 & 242.7 & 85.0 & 52.9 & 1010.4 & 188.9 & 31.2 \\
\hline 11 & 722.9 & 36 & 94.5 & 62.7 & ND & 58.7 & 36.6 & 150.8 & 140.5 & 38.4 & 674.4 & 108.7 & 46.2 \\
\hline 12 & 502.4 & 7.9 & 28.5 & 20 & 4.5 & 32.5 & 59.2 & 323.1 & 83.7 & 63.4 & 762.8 & 120.4 & 36.5 \\
\hline 13 & 593.6 & ND & 14.8 & 18.6 & 2.0 & 18.2 & 47.4 & 201.2 & 58.1 & 41.9 & 882.2 & 101.5 & 29.2 \\
\hline 14 & 452.4 & ND & 15.4 & 12.3 & 7.8 & 20.9 & 60.2 & 332.7 & 74.6 & 33.4 & 634.5 & 121.7 & 47.6 \\
\hline 15 & 653.4 & 6.7 & 48.6 & 17.5 & 4.2 & 29.6 & 43.0 & 191.2 & 89.0 & 36.1 & 549.3 & 170.9 & 43.9 \\
\hline 16 & 522.5 & ND & 14.5 & 15.0 & 4.9 & 16.5 & 53.7 & 266.5 & 66.25 & 37.65 & 758 & 111.5 & 38.34 \\
\hline 17 & 606.59 & 5.4 & 22.2 & 15.0 & 6.65 & 24.5 & 54.7 & 274.5 & 67.099 & 45.45 & 652.2 & 136.5 & 38.0 \\
\hline 18 & 532.0 & 9.0 & 39.09 & 22.95 & 5.4 & 27.2 & 51.8 & 232 & 88.150 & 45.79 & 746.0 & 160.6 & 53.95 \\
\hline 19 & 602.79 & 7.07 & 48.59 & 24.14 & 5.4 & 31.0 & 52.6 & 201.6 & 88.150 & 43.93 & 746.0 & 146.5 & 51.27 \\
\hline 20 & 592.90 & 14.0 & 57.00 & 29.85 & 3.39 & 39.0 & 50.0 & 166.4 & 451.75 & 37.90 & 634.0 & 120.1 & 49.29 \\
\hline 21 & 597.0 & 10.5 & 52.50 & 28.92 & 2.00 & 35.0 & 51.3 & 184.0 & 269.95 & 40.90 & 690.0 & 133.4 & 50.29 \\
\hline 22 & 625.0 & 31.6 & 64.80 & 35.7 & 2.69 & 41.1 & 43.6 & 175.3 & 166.47 & 38.43 & 637.5 & 137.6 & 46.79 \\
\hline 23 & 639.0 & 14.8 & 58.90 & 24.39 & 1.72 & 30.2 & 41.9 & 202.8 & 113.40 & 42.43 & 732.2 & 165.4 & 40.63 \\
\hline 24 & 744.59 & 5.4 & 29.00 & 18.89 & 5.50 & 28.2 & 49.2 & 217.0 & 74.599 & 33.29 & 634.5 & 151.3 & 47.59 \\
\hline 25 & 58.75 & 10.0 & 49.0 & 25.96 & 4.25 & 33 & 51.0 & 195.0 & 224.0 & 81.0 & 704 & 139.7 & 50.0 \\
\hline
\end{tabular}


Table 5. Statistical summary of the heavy metal concentration of soil of the study area and the reference value in the continental crust (Taylor and McLennan 1995).

\begin{tabular}{lrrrccr}
\hline Elements & Min. & Max. & Mean & $\begin{array}{c}\text { Stand. } \\
\text { deviation }\end{array}$ & $\begin{array}{c}\text { Coef. } \\
\text { variance } \%\end{array}$ & $\begin{array}{c}\text { Reference } \\
\text { value }\end{array}$ \\
\hline $\mathrm{Ba}$ & 58.75 & 744.6 & 551.77 & 160.58 & 92 & 550 \\
$\mathrm{Co}$ & 5.4 & 36 & 14.908 & 9.288 & 85 & 10 \\
$\mathrm{Cr}$ & 3.2 & 106.3 & 45.631 & 24.495 & 97 & 35 \\
$\mathrm{Cu}$ & 11.8 & 62.7 & 24.439 & 10.676 & 81 & 25 \\
$\mathrm{Mo}$ & 1.1 & 8.1 & 4.644 & 2.01 & 86 & 1.5 \\
$\mathrm{Ni}$ & 10.3 & 74.9 & 33.427 & 14.664 & 86 & 20 \\
$\mathrm{~Pb}$ & 36.6 & 71.5 & 52.573 & 8.421 & 49 & 20 \\
$\mathrm{Rb}$ & 126.9 & 1314 & 279.46 & 236.33 & 90 & 112 \\
$\mathrm{~V}$ & 18.4 & 451.75 & 116.29 & 87.684 & 96 & 60 \\
$\mathrm{Y}$ & 27.6 & 153.3 & 48.778 & 25.137 & 82 & 22 \\
$\mathrm{Zr}$ & 66.3 & 1010.4 & 628.6 & 197.67 & 93 & 190 \\
$\mathrm{Sr}$ & 89 & 295.4 & 147.39 & 48.619 & 70 & 350 \\
$\mathrm{Zn}$ & 25.3 & 60.4 & 44.325 & 9.396 & 58 & 71 \\
\hline
\end{tabular}

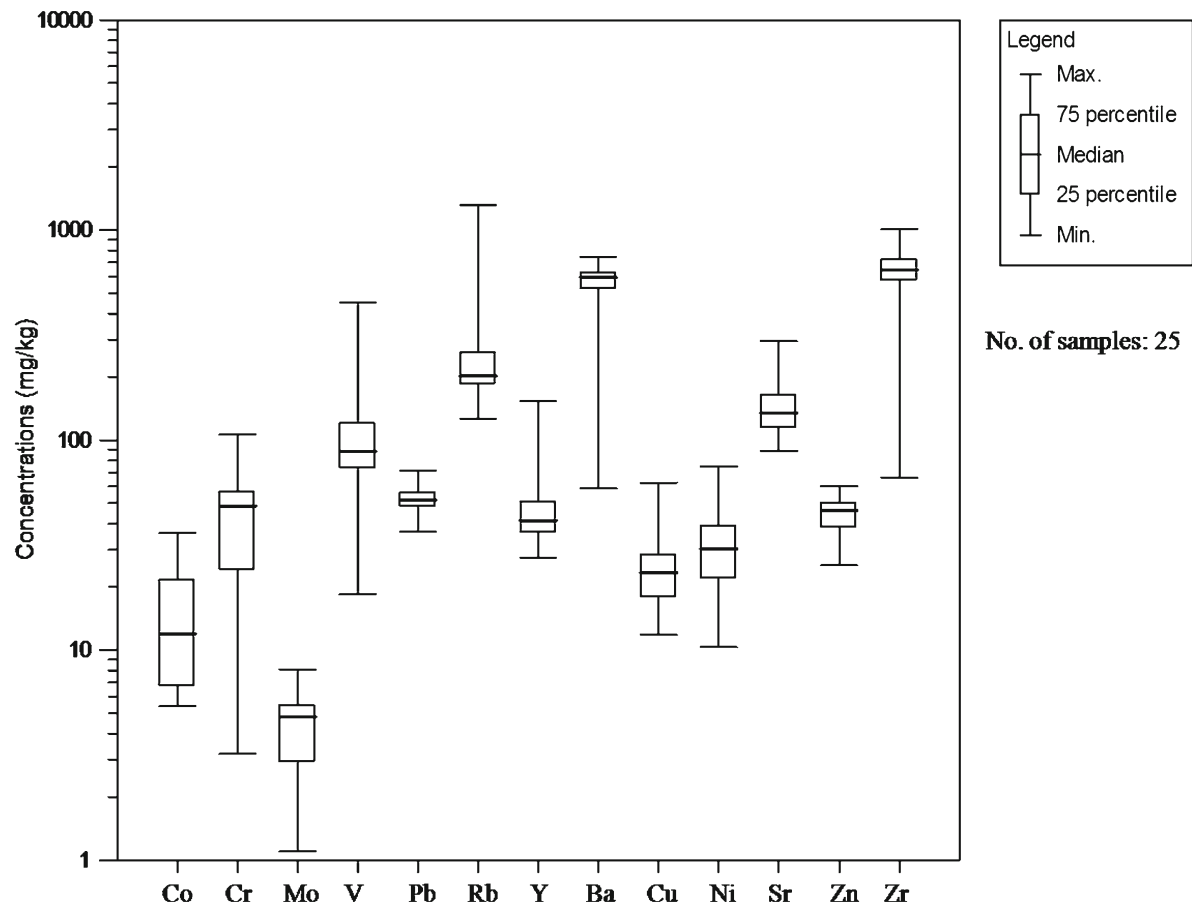

Figure 4. Distribution of heavy metals in soil samples of the study area as revealed in the box plot diagram.

actual value. Hence IDW interpolation method was found reliable for the present study.

The concentration of strontium and zinc is within the desirable limits; hence these elements are not discussed below.

\subsubsection{Barium}

The main source of barium in the study area is predominant siliceous soils. Barium concentration in the soils of the study area ranges from 130.3$744.6 \mathrm{mg} / \mathrm{kg}$ with an average of $551.77 \mathrm{mg} / \mathrm{kg}$. Sixty-eight percent samples exceed the limit of $550 \mathrm{mg} / \mathrm{kg}$. The spatial variation map shows that barium concentration is more in the northern part of the study area (figure 5a). Source of barium could be both geogenic and anthropogenic. The high standard deviation of barium indicates that it is not distributed uniformly within the area. The high barium concentration can be attributed to 


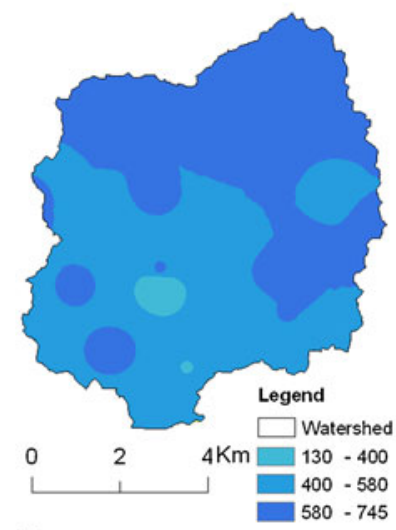

(a) Barium

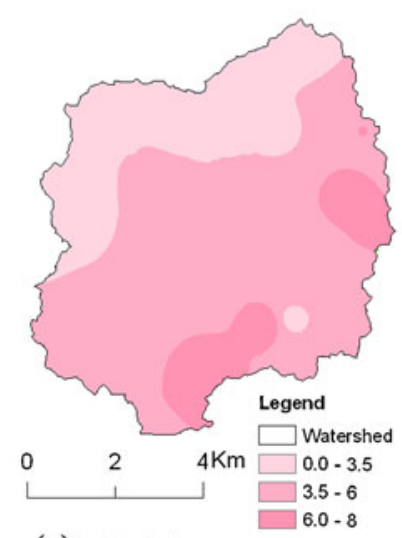

(e) Molybdenum

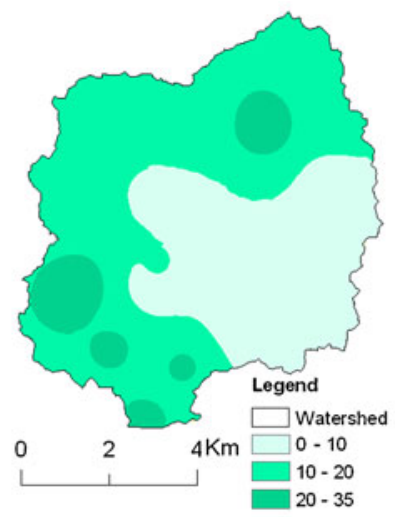

(b) Cobalt

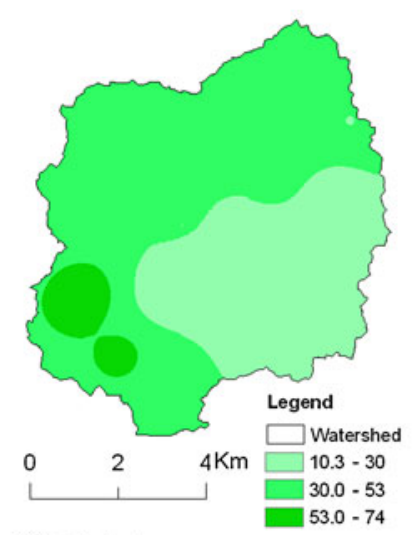

(f) Nickel

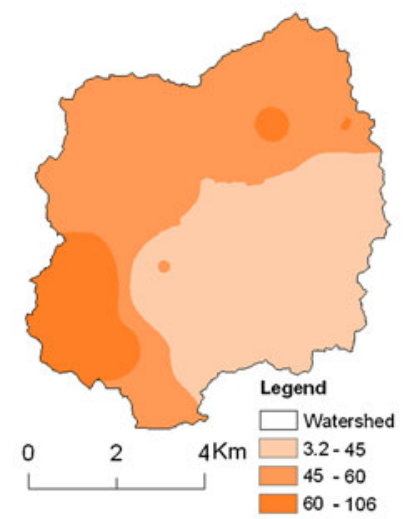

(c) Chromium

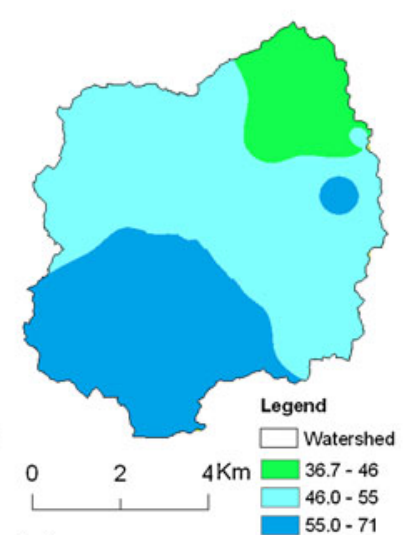

(g) Lead

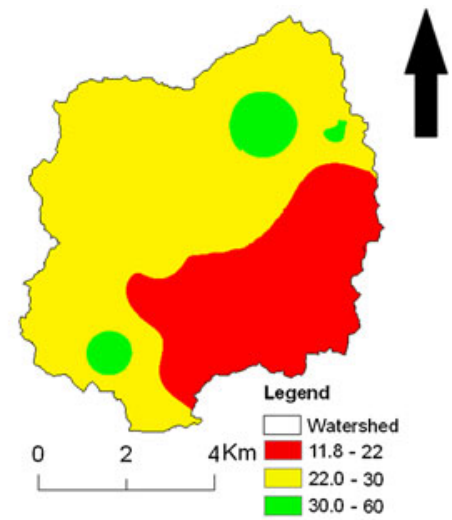

(d) Copper

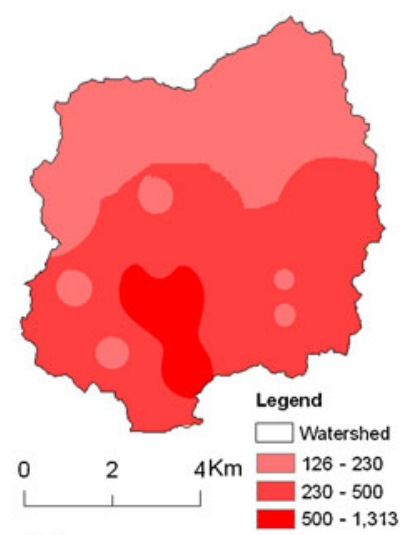

(h) Rubidium

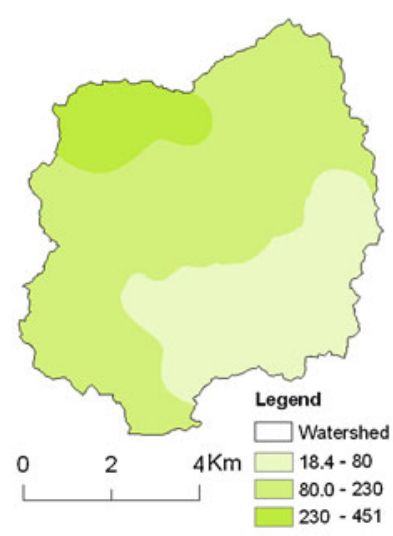

(I) Vanadium

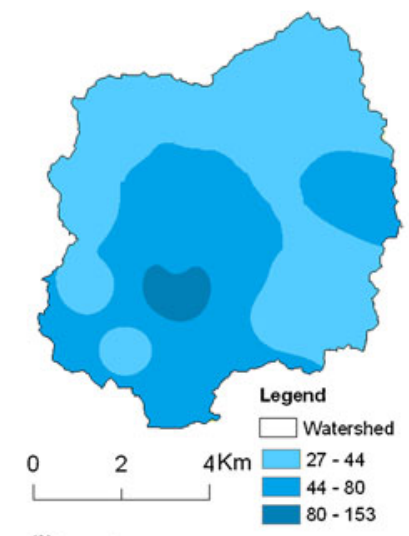

(j) Yttrium

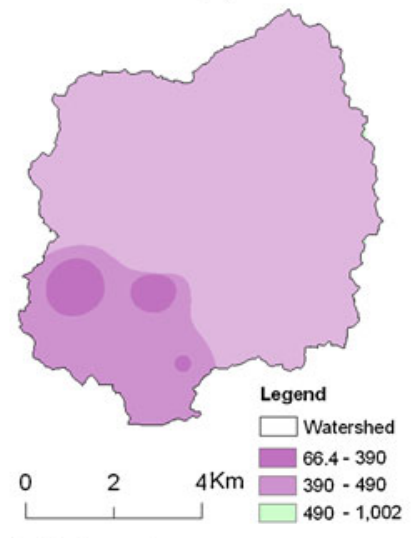

(k) Zirconium

Figure 5. (a-k) Spatial variability maps showing distribution of heavy metals in the soil of the study area.

feldspar weathering in silicate rocks (Govil et al. 2001).

\subsubsection{Cobalt}

The cobalt concentration in the soils of the study area varies from $5.4-36.0 \mathrm{mg} / \mathrm{kg}$ with an average of $14.90 \mathrm{mg} / \mathrm{kg}$. Sixty-six percent of cobalt samples exceed the desirable limit of $10 \mathrm{mg} / \mathrm{kg}$. The spatial distribution shows that the concentration of cobalt is high in north, south and northwestern parts of watershed (figure 5b). The main source of cobalt concentration is dumping of untreated domestic and municipal waste and application of cobalt salts or cobalt treated phosphate fertilizers (Smith and Paterson 1995).

\subsubsection{Chromium}

Sixty-eight percent of chromium samples are beyond the desirable limit of $35 \mathrm{mg} / \mathrm{kg}$. The 
concentration of chromium varies from 3.2$106.3 \mathrm{mg} / \mathrm{kg}$ with an average of $45.63 \mathrm{mg} / \mathrm{kg}$. The main source of chromium is steel producing industries in the area, chromeplating and pigment production is the main source of chromium contamination in the area. However, inadequate disposal of waste containing chromium at industrial sites has contaminated the land and groundwater. The spatial distribution of chromium is given in the variation map (figure $5 \mathrm{c}$ ).

\subsubsection{Copper}

Copper concentration varies from $11.8-62.7 \mathrm{mg} / \mathrm{kg}$ with an average of $24.43 \mathrm{mg} / \mathrm{kg}$. Twenty-five percent of copper samples exceed the desirable limit of $25 \mathrm{mg} / \mathrm{kg}$. The spatial distribution of copper in the study area is given in figure $5(\mathrm{~d})$. Copper accumulation in the soil of the study area is due to the industries like steel manufacture and application of agrochemicals in the agro-based industry. The abundance of copper in igneous rocks is partly controlled by the process of differentiation during crystallization (Dantu 2009).

\subsubsection{Molybdenum}

The molybdenum concentration ranges from 1.1$8.1 \mathrm{mg} / \mathrm{kg}$ with an average concentration of $4.64 \mathrm{mg} / \mathrm{kg}$. Ninety-two percent of molybdenum samples are beyond the desirable limit. The spatial distribution map showing molybdenum is given in figure $5(\mathrm{e})$.

\subsubsection{Nickel}

The spatial distribution of nickel is given in the variation map (figure $5 \mathrm{f}$ ). Nickel concentration ranges from $10.3-74.9 \mathrm{mg} / \mathrm{kg}$ with an average of $33.42 \mathrm{mg} / \mathrm{kg}$. Eighty-four percent of nickel samples are beyond the desirable limit of $20 \mathrm{mg} / \mathrm{kg}$. Sources of nickel in soil include contamination from municipal sewage sludge, waste water from sewage treatment plants and groundwater near landfill sites.

\subsubsection{Lead}

The average concentration of lead in the study area is $52.57 \mathrm{mg} / \mathrm{kg}$. The concentration of lead of the area ranges from $36.6-71.5 \mathrm{mg} / \mathrm{kg}$. Hundred percent of the lead samples are beyond the desirable limit of $20 \mathrm{mg} / \mathrm{kg}$. The spatial distribution shows increasing trend from north to south of watershed (figure $5 \mathrm{~g}$ ). Main source of lead pollution in the area is due to electroplating of metals, excessive traffic and corrosion of lead pipes.

\subsubsection{Rubidium}

The concentration of rubidium in soils of the study area ranges from $126.9-1314 \mathrm{mg} / \mathrm{kg}$. Hundred percent of rubidium samples are beyond desirable limit of $112 \mathrm{mg} / \mathrm{kg}$. The source of rubidium is geogenic as soils over granites and gneiss have highest mean rubidium content of $110-120 \mathrm{mg} / \mathrm{kg}$ (Pendias and Mukherjee 2007). The standard deviation is very high showing that the distribution of rubidium is not uniform. The spatial distribution of rubidium is given in figure $5(\mathrm{~h})$.

\subsubsection{Vanadium}

The concentration of vanadium in the soil of the study area ranges from $18.4-123.3 \mathrm{mg} / \mathrm{kg}$ with an average of $116.29 \mathrm{mg} / \mathrm{kg}$. Eighty-eight percent of vanadium samples crossed the desirable limit of $60 \mathrm{mg} / \mathrm{kg}$. The spatial distribution of vanadium is given in figure 5(i). The high standard deviation shows that vanadium is not uniformly distributed in the area. Vanadium is used in many industries like textile, electronics, dyeing and metallurgy. Therefore the source of this element is directly associated with these industries.

\subsubsection{Yttrium}

The concentration of Yttrium ranges from 27.6$153.3 \mathrm{mg} / \mathrm{kg}$. Hundred percent of yttrium samples crossed the limit of $22 \mathrm{mg} / \mathrm{kg}$. Yttrium is dumped in the environment in many different places, mainly by petrol-producing industries. With water yttrium causes damage to cell membranes, which has several negative influences on reproduction and on the functions of the nervous system. The distribution of yttrium is given in figure $5(\mathrm{j})$.

\subsubsection{Zirconium}

The concentration of zirconium ranges from 66.3$1010.4 \mathrm{mg} / \mathrm{kg}$. Ninety percent of zirconium samples crossed the limits of $190 \mathrm{mg} / \mathrm{kg}$. High standard deviation of the element shows its uneven distribution in the area (figure $5 \mathrm{k}$ ). The source of zirconium in the area is industries producing surgical equipments and manufacture of furnace bricks.

The result of FA based on the most significant first five factors shows that about $90 \%$ of the total variance and include 11 variables (elements) of the observed 13 variables. Hence, the first five factors 
can be used to explain the factors contributing to soil contamination in the area.

The following sources of contamination exist within the industrial area:

- The unplanned setup of industries.

- Random location of dump sites of solid waste throughout the area.

- The discharge of untreated industrial effluent into groundwater.

- Emission from smokestacks.

- Indiscriminate use of fertilizers, pesticides, etc.

\subsection{Major oxides in the soil}

Soil samples collected throughout the agriculture, residential and industrial areas are analysed for heavy metals and major oxides. Results of chemical analysis of major oxides $\left(\mathrm{SiO}_{2}, \mathrm{Al}_{2} \mathrm{O}_{3}, \mathrm{Fe}_{2} \mathrm{O}_{3}\right.$, $\mathrm{MnO}, \mathrm{MgO}, \mathrm{CaO}, \mathrm{Na}_{2} \mathrm{O}, \mathrm{K}_{2} \mathrm{O}, \mathrm{TiO}_{2}$ and $\mathrm{P}_{2} \mathrm{O}_{5}$ ) were compared with the international standards for major oxides in soil by Bohn et al. (2001) (table 6) and is useful to classify soils on the basis of their chemical composition. The concentration of major oxides was compared with the reference values given by for the major oxide concentration in soil in weight percent.

The $\mathrm{SiO}_{2}$ concentration varies from $50.09-70.5 \%$. Hundred percent of $\mathrm{SiO}_{2}$ samples are within the limit of $72.64 \%$ as recommended Bohn et al. (2001).

$\mathrm{Al}_{2} \mathrm{O}_{3}$ concentration varies from $14.28-23.74 \%$; all the $\mathrm{Al}_{2} \mathrm{O}_{3}$ samples are beyond the limit of $13.22 \%$. $\mathrm{Fe}_{2} \mathrm{O}_{3}$ values range from $1.43-7.91 \% ; 80 \%$ of $\mathrm{Fe}_{2} \mathrm{O}_{3}$ samples crossed the limit of $5.77 \%$. All the samples of $\mathrm{MnO}$ and $\mathrm{MgO}$ are within limits of $0.1 \%$ and $0.99 \%$, respectively.

The concentration of $\mathrm{CaO}$ ranges between 0.34 and $2.55 \% ; 84 \%$ of $\mathrm{CaO}$ samples crossed the limit of $1.44 \%$. The $\mathrm{Na}_{2} \mathrm{O}$ samples range between 0.39 and $2.96 \% ; 52 \%$ of $\mathrm{Na}_{2} \mathrm{O}$ have crossed the standard limit of $0.99 \%$. Hundred percent $\mathrm{K}_{2} \mathrm{O}$ samples are beyond the desirable limit of $1.2 \%$. The concentration of $\mathrm{K}_{2} \mathrm{O}$ ranges from 2.7-9.11\%. All the $\mathrm{TiO}_{2}$ samples are within the limit of $0.88 \%$. The concentration of $\mathrm{P}_{2} \mathrm{O}_{5}$ ranges from $0.04-0.19 \%$; $8 \%$ of $\mathrm{P}_{2} \mathrm{O}_{5}$ samples are beyond the limit of $0.18 \%$.

Table 6. Statistical summary of major oxide concentration in soil samples of the study area and the reference value (Bohn et al. 2001).

\begin{tabular}{|c|c|c|c|c|c|c|c|c|c|c|}
\hline $\begin{array}{l}\text { Sample } \\
\text { no. }\end{array}$ & $\begin{array}{c}\mathrm{SiO}_{2} \\
(\%)\end{array}$ & $\begin{array}{c}\mathrm{Al}_{2} \mathrm{O}_{3} \\
(\%)\end{array}$ & $\begin{array}{c}\mathrm{Fe}_{2} \mathrm{O}_{3} \\
(\%)\end{array}$ & $\begin{array}{c}\mathrm{MnO} \\
(\%)\end{array}$ & $\begin{array}{c}\mathrm{MgO} \\
(\%)\end{array}$ & $\begin{array}{l}\mathrm{CaO} \\
(\%)\end{array}$ & $\begin{array}{c}\mathrm{Na}_{2} \mathrm{O} \\
(\%)\end{array}$ & $\begin{array}{c}\mathrm{K}_{2} \mathrm{O} \\
(\%)\end{array}$ & $\begin{array}{c}\mathrm{TiO}_{2} \\
(\%)\end{array}$ & $\begin{array}{c}\mathrm{P}_{2} \mathrm{O}_{5} \\
(\%)\end{array}$ \\
\hline 1 & 61.38 & 19.45 & 4.41 & 0.04 & ND & 0.79 & 0.65 & 4.39 & 0.48 & 0.07 \\
\hline 2 & 55.78 & 17.81 & 4.85 & 0.05 & 0.43 & 2.55 & 0.90 & 3.51 & 0.60 & 0.14 \\
\hline 3 & 51.76 & 23.17 & 6.86 & 0.04 & 0.02 & 0.67 & 0.59 & 3.18 & 0.75 & 0.07 \\
\hline 4 & 50.10 & 23.74 & 7.91 & 0.04 & 0.11 & 0.58 & 0.39 & 2.89 & 0.73 & 0.07 \\
\hline 5 & 59.94 & 15.79 & 4.36 & 0.06 & 0.46 & 1.41 & 1.53 & 4.29 & 0.65 & 0.11 \\
\hline 6 & 60.98 & 17.34 & 3.30 & 0.03 & ND & 0.85 & 1.15 & 4.99 & 0.57 & 0.08 \\
\hline 7 & 63.60 & 17.95 & 1.43 & 0.02 & ND & 0.42 & 2.96 & 9.11 & 0.11 & 0.04 \\
\hline 8 & 68.80 & 14.95 & 2.14 & 0.04 & ND & 0.43 & 1.51 & 6.01 & 0.37 & 0.06 \\
\hline 9 & 60.79 & 18.29 & 3.61 & 0.03 & ND & 0.66 & 0.82 & 4.98 & 0.47 & 0.09 \\
\hline 10 & 64.23 & 14.98 & 3.00 & 0.04 & ND & 0.92 & 1.03 & 4.82 & 0.52 & 0.09 \\
\hline 11 & 55.89 & 19.07 & 7.50 & 0.09 & 0.03 & 1.15 & 0.61 & 2.70 & 0.82 & 0.07 \\
\hline 12 & 61.82 & 17.73 & 3.50 & 0.05 & ND & 0.56 & 1.01 & 4.91 & 0.53 & 0.07 \\
\hline 13 & 70.50 & 14.54 & 2.13 & 0.02 & ND & 0.40 & 0.98 & 5.97 & 0.34 & 0.06 \\
\hline 14 & 64.61 & 16.13 & 3.23 & 0.03 & 0.09 & 1.12 & 1.66 & 4.51 & 0.46 & 0.19 \\
\hline 15 & 60.73 & 16.53 & 3.45 & 0.03 & 0.26 & 1.33 & 1.13 & 4.34 & 0.55 & 0.16 \\
\hline 16 & 58.85 & 18.71 & 5.35 & 0.07 & 0.03 & 0.85 & 0.81 & 3.80 & 0.67 & 0.08 \\
\hline 17 & 64.89 & 16.14 & 2.72 & 0.03 & ND & 0.64 & 1.33 & 5.5 & 0.47 & 0.07 \\
\hline 18 & 60.46 & 16.56 & 3.83 & 0.04 & 0.44 & 1.13 & 1.34 & 4.64 & 0.61 & 0.09 \\
\hline 19 & 60.66 & 17.54 & 4.37 & 0.05 & 0.47 & 1.21 & 1.31 & 4.36 & 0.57 & 0.09 \\
\hline 20 & 58.65 & 18.53 & 4.72 & 0.03 & 0.43 & 1.67 & 0.84 & 4.15 & 0.54 & 0.15 \\
\hline 21 & 65.69 & 16.45 & 2.67 & 0.15 & ND & 0.58 & 0.86 & 5.37 & 0.43 & 0.07 \\
\hline 22 & 70.21 & 22.50 & 5.89 & 0.05 & 0.03 & 2.12 & 2.45 & 5.28 & 0.70 & 0.09 \\
\hline 23 & 63.42 & 15.13 & 1.97 & 0.02 & 0.41 & 0.65 & 1.46 & 2.90 & 0.14 & 0.05 \\
\hline 24 & 50.09 & 14.28 & 3.84 & 0.06 & ND & 0.34 & 0.67 & 4.64 & 0.39 & 0.08 \\
\hline 25 & 55.98 & 17.85 & 6.27 & 0.04 & 0.32 & 1.56 & 0.93 & 4.18 & 0.62 & 0.19 \\
\hline Reference value & 70.29 & $>13.22$ & 5.77 & $>0.1$ & 0.99 & 1.44 & 0.99 & 1.2 & 0.88 & 0.18 \\
\hline
\end{tabular}


Based on the major oxide distribution, it is observed that these soils are predominantly siliceous type with slight enrichment of alumina component in the study area. These soils are typical of semi-arid, sub-tropical mode of weathering in a granite terrain and display the inherent characteristic of silica and alumina of the parent rock.

\section{Conclusions and recommendations}

The study demonstrates that soil quality in the watershed is degrading. By application of FA and GIS we are able to delineate the contamination zones for heavy metal pollution. These figures can have serious impact on the land use and soil management in the area in particular and the areas with similar conditions in general. Soil is one of the important parts of the biosphere. Therefore the concerned planners should take the issue seriously for the present and future of our planet. The study area is facing the problem of soil and water quality deterioration, due to the absence of perennial source of surface water, inadequate rainfall and overexploitation. Water quality has also deteriorated due to increased human population, rapid urbanization, unscientific disposal of water and improper water management. Change in land use pattern directly resulted in the degradation of hydro-geological environment. In the industrial area, the haphazard dumping of hazardous waste is the main cause of the contaminant spreading by rain water and wind. In the residential areas the local dumping is expected to be the main source as it is difficult to foresee that rain and wind can transport the contaminants from the industrial area. The following preventive measures are proposed to curb soil pollution. All random dumping of industrial wastes must terminate (and collection system for domestic waste). A local landfill site should be established for temporarily receiving waste and for bulk transport to the nearby permanent landfill site and clean up all existing waste. The extent of the contamination by Ba, Co, $\mathrm{Cr}, \mathrm{Cu}, \mathrm{Mo}, \mathrm{Ni}, \mathrm{Pb}, \mathrm{Rb}, \mathrm{V}, \mathrm{Y}$ and $\mathrm{Zr}$ established by preparing spatial variation maps, the areas should be treated as sensitive for further research. Possible options of remedial measures can be excavation and replanting, stabilization of the soil, phyto-remediation, bio-remediation. It is recommended to have a periodical monitoring of the environment in this area and necessary and mitigative measures be implemented to avoid further deterioration of the environment for sustainable development. The processes responsible for degradation of soil quality is long term phenomenon, therefore detailed monitoring of soil quality in such areas should be taken into consideration.

\section{Acknowledgements}

The authors are thankful to Prof. Mrinal K Sen, Director, NGRI, Hyderabad, for his encouragement and permission to publish this paper. Thanks are due to Dr A K Krishna for his help during soil analysis.

\section{References}

Abrahams P W 2002 Soils: Their implications to human health; The Science of the Total Environ. 29 11-32.

Ahmad J and Goni A M 2010 Heavy metal contamination in water, soil, and vegetables of the industrial areas in Dhaka, Bangladesh; Environ. Monit. Assess. 166 347-357.

Bai J, Yang Z, Cui B, Wang Q, Gao H and Ding Q 2009 Assessment of heavy metal contamination of roadside soils in southwest China; Stoch. Environ. Res. Risk Assess. 23 341-347.

Bai J, Yang Z, Cui B, Gao H and Ding Q 2010 Some heavy metals distribution in wetland soils under different landuse types along a typical plateau lake, China; Soil $\&$ Tillage Res. 106 344-348.

Bai J, Xiao R, Cui B, Zhang K, Wang Q, Liu X, Gao H and Huang L 2011 Assessment of heavy metal pollution in wetland soils from the young and old reclaimed regions in the Pearl River Estuary, South China; Environ. Pollut. $159817-824$.

Bohn L H, McNeal L B and O'Connor A G 2001 Soil Chemistry; 2nd edn (New York: John Wiley).

Chang A C, Warneke J E, Page A L and Lund L J 1984 Accumulation of heavy metals in sewage sludge treated soils; J. Environ. Qual. 13 87-91.

Dantu S 2009 Heavy metals concentration in soils of southeastern part of Ranga Reddy district, Andhra Pradesh, India; Environ. Monit. Assess. 149 213-222.

Davis J C 1986 Statistics and data analysis in geology (New York: John Wiley), 646p.

Davis B M 1987 Uses and abuses of cross-validation in geostatistics; Math. Geol. 19 241-248.

Denny P 1987 Monitoring of heavy metals - A proposed strategy for developing countries; In: Lead, mercury, cadmium and arsenic in the environment (eds) Hutchinson $\mathrm{T}$ C and Meema K M (New York: John Wiley), pp. 343-347.

Dewandel B, Lachassange P, Wyns R, Marechal J C and Krishnamurthy N S 2006 A generalized 3-D geological and hydrogeological conceptual model of granite aquifers controlled by single or multi-phase weathering; J. Hydrol. 3 260-284.

Frink C R 1996 A perspective on metals in soils; J. Soil Contamination 59 329-359.

Govil P K, Reddy G L N and Krishna A K 2001 Contamination of soil due to heavymetals in Patancheru industrial development area, Andhra Pradesh, India; Environ. Geol. $41461-469$.

Jeevan R K 1998 Heavy metal inputs to soils by agricultural activities; Environ. Geochem. 1 15-18.

Karanlık S, Ağca N and Yalçın M 2011 Spatial distribution of heavy metals content in soils of Amik Plain Hatay, Turkey; Environ. Monit. Assess. 173 181-191. 
Krishna A K and Govil P K 2008 Assessment of heavy metal contamination in soils around Manali industrial area, Chennai, Southern India; Environ. Geol. 54 $1465-1472$.

Li X and Huang C 2007 Environment impact of heavy metals on urban soil in the vicinity of industrial area of Baoji city, P.R. China; Environ. Geol. 52 1631-1637.

Matlab 6.5: 2002 The language of technical computing; The MathWorks, Inc.3 Apple Hill Drive, Natick, MA 017602098.

Olade M A 1987 Heavy metal pollution and the need for monitoring: Illustration for developing countries in West Africa; In: Lead, mercury, cadmium and arsenic in the environment (eds) Huchinson $\mathrm{T} \mathrm{C}$ and Meema K M (New York: Wiley), pp. 335-341.
Pendias K A and Mukherjee B A 2007 Trace Elements from Soil to Humans (Berlin: Springer), pp. 93-94.

Romic M and Romic D 2003 Heavy metal distribution in agricultural top soils in urban area; Environ. Geol. 43 795-805.

Smith K A and Paterson J E 1995 Manganese and cobalt; In: Heavy Metals in Soils (ed.) Alloway B L (Glasgow: Chapman \& Hall), pp. 224-244.

Taylor S R and McLennan S M 1995 The geochemical evolution of the continental crust; Rev. Geophys. 33 241-265.

Wu S, Zhou S, Li X, Jackson T and Zhu Q 2011 An approach to partition the anthropogenic and natural components of heavy metal accumulations in roadside agricultural soil; Environ. Monit. Assess. 173 871-881. 